\title{
Frullania knightbridgei, a new liverwort (Frullaniaceae, Marchantiophyta) species from the deep south of Aotearoa-New Zealand based on an integrated evidence-based approach
}

\author{
Matt von Konrat', Peter de Lange'2, Matt Greif ${ }^{1,3}$, Lynika Strozier' \\ Jörn Hentschel ${ }^{4}$, Jochen Heinrichs ${ }^{5}$
}

I Department of Botany, The Field Museum, 1400 South Lake Shore Drive, Chicago IL 60605-2496, USA

2 Ecosystems and Species Unit, Department of Conservation, New Zealand 3 Biology Department, Wilbur Wright College, 4300 N. Narragansett, Chicago, IL, USA 4 Department of Systematic Botany with Herbarium Haussknecht and Botanical Garden, Friedrich Schiller University, Fürstengraben 1, 07743 Jena, Germany 5 Department of Systematic Botany, Albrecht von Haller Institute of Plant Sciences, Georg August University, Untere Karspüle 2, 37073 Göttingen, Germany

Corresponding author: Matt von Konrat (mvonkonrat@fieldmuseum.org)

Academic editor: W. J. Kress | Received 5 December 2011 | Accepted 19 December 2011 | Published 2 January 2012

Citation: von Konrat M, de Lange P, Matt Greif M, Strozier L, Hentschel J, Heinrichs J (2012) Frullania knightbridgei, a new liverwort (Frullaniaceae, Marchantiophyta) species from the deep south of Aotearoa-New Zealand based on an integrated evidence-based approach. PhytoKeys 8: 13-36. doi: 10.3897/phytokeys.8.2496

\begin{abstract}
Frullania is a large and taxonomically complex genus. A new liverwort species, Frullania knightbridgei sp. nov. from southern New Zealand, is described and illustrated. The new species, and its placement in Frullania subg. Microfrullania, is based on an integrated evidence-based approach derived from morphology, ecology, experimental growth studies of plasticity, as well as sequence data. Diagnostic characters associated with the leaf and lobule cell-wall anatomy, oil bodies, and spore ultra-structure distinguish it from all other New Zealand species of Frullania. A critical comparison is also made between Frullania knightbridgei and morphologically allied species of botanical regions outside the New Zealand region and an artificial key is provided. The new species is similar to some forms of the widespread Australasian species, F. rostrata, but has unique characters associated with the lobule and oil bodies. Frullania knightbridgei is remarkably interesting in comparison with the majority of Frullania species, and indeed liverworts in general, in that it is at least partially halotolerant. Maximum parsimony and maximum likelihood analyses of nuclear ribosomal ITS2 and plastidic trnL-trnF sequences from purported related species confirms its independent taxonomic status and corroborates its placement within Frullania subg. Microfrullania.
\end{abstract}

Copyright Matt von Konrat et al. This is an open access article distributed under the terms of the Creative Commons Attribution License 3.0 (CC-BY), which permits unrestricted use, distribution, and reproduction in any medium, provided the original author and source are credited. 


\section{Keywords}

Frullaniaceae, Frullania, subg. Microfrullania, Frullania knightbridgei sp. nov., morphology, DNA sequence data, New Zealand Flora, halotolerant liverwort

\section{Introduction}

Frullania Raddi (Frullaniaceae) is a large and complex liverwort (Marchantiophyta) genus with a worldwide distribution (Yuzawa 1991, von Konrat and Braggins 2001a). The number of published Frullania names has been reported to be over 2000 (von Konrat et al. 2010). Published estimates of the number of accepted species for the genus that have become widely recognized range from 300-375 accepted species (e.g., Schuster 1992, Gradstein et al. 2001). However, there is no evidence whatsoever to support these suppositions as no worldwide monographic treatment of Frullania has ever been attempted (von Konrat et al. 2006a, 2010). On the contrary, growing data and evidence may suggest the number of 300-375 species is a minimum estimate at best (von Konrat et al. 2010); in some cases the underestimation of the Frullania species diversity has been attributed to conservative morphology within species complexes (Heinrichs et al. 2010). In New Zealand, the current number of accepted taxa is 33 , including 31 species and two varieties of which 10 are apparently endemic (Hattori 1979a, b; 1983; Glenny 1998; von Konrat and Braggins 2005; von Konrat et al. 2006b; von Konrat et al. 2010, 2011, this issue). Here we present a study of a newly discovered species that is morphologically close to Frullania rostrata (Hook. f. et Taylor) Hook. f. et Taylor, which is considered a widespread, polymorphic and common Australasian species (von Konrat et al. 2006b). The new species would be lumped under $F$. rostrata based on overall gross morphology.

Our paper is part of a broader, on-going, regional study of Frullania species by us that includes the botanical regions of New Zealand, Australia, the Pacific, South East Asia, and South America. Our new species occurs on Stewart Island/Rakiura and the Auckland Islands group of the New Zealand botanical region (as defined by de Lange and Rolfe 2010). Both areas are regarded as extremely biologically and biogeographically significant (Given and Hnatiuk 1995; McGlone and Wilson 1996; Wilson 1987; Wagstaff et al. 2011). Stewart Island/Rakiura, is the southernmost and third largest island of the New Zealand archipelago, with about $85 \%$ of the island comprising Rakiura National Park (Heenan et al. 2009). Although the fauna and flora has been partially modified as a consequence of historical Maori and European settlement, the island's vegetation patterns are little altered from their pre-human state (Wilson 1987). On the other hand, the Auckland Island group is one of five New Zealand sub-Antarctic island groups (including Snares, Bounty, Antipodes, Auckland, and Campbell islands) and are all World Heritage Areas (Chown et al. 2008). The distinctive flora of the subantarctic islands includes some of the last remnants of a once-diverse Antarctic flora, with examples of many plants possibly still retaining distinctive features of their ancestors (Wagstaff et al. 2011). 
The new species of Frullania described below is assigned to Frullania subg. Microfrullania (R.M.Schust.) R.M.Schust., which is confirmed by molecular evidence. Detailed microscopic and SEM micrographs as well as a brief comparison with morphologically similar species are provided. This new species is remarkable in comparison with the majority of Frullania species in New Zealand for its least partial tolerance and exposure to salt spray. For consistency and clarity through this article, the results and discussion that follows refers to the newly recognised species as Frullania knightbridgei.

\section{Methods}

\section{Living material}

In order to monitor the stability of character-states and assess whether some characters varied independently of the genotype, material was grown under uniform environmental conditions described by von Konrat and Braggins (2001a). The same individual colonies were grown under three different light and water regimes and characters subsequently monitored for stability or variation. Voucher specimens of cultivated material are deposited at $\mathrm{AK}$ and $\mathrm{F}$.

\section{Herbarium material}

Dried herbarium material was examined from AK, AKU, CANB, BM, CRI, F, G, GOET, MEL, MELU, MPN, NICH, NY, P, S, WELT, and WTU. Herbarium acronyms follow Holmgren and Holmgren (2003).

\section{Morphological study}

Where necessary, plant material was cleared to remove pigmentation using the method outlined by von Konrat and Braggins (2001a) and the cell layers of the capsule wall were separated as described by von Konrat et al. (1999). Microscopy techniques, measurements, the use of descriptors to indicate abundance and frequency, terminology of spore ornamentation, preparation of material (including spores for the SEM studies) are outlined in detail by von Konrat and Braggins (2001b) and von Konrat et al. (2006a, b).

\section{DNA extraction, PCR amplification and sequencing}

Dried tissue was disrupted with the aid of a sterile steel bead in a Qiagen tissuelyser (Qiagen Inc. Hilden, Germany) set at $30 \mathrm{~Hz}$ for $45 \mathrm{~s}$. Genomic DNA was extracted and 
purified using an Invisorb Spin Plant Mini Kit (Invitek, Berlin, Germany) according to the manufacturer's specifications. Two molecular markers, the internal transcribed spacer 2 of nuclear ribosomal DNA, and the plastidic trnL-F region were sequenced using the primer sets presented by Hartmann et al. (2006) and Gradstein et al. (2006). Approximately 525 base pairs (bp) of the 5.8S-nrITS2 region were sequenced, along with $500 \mathrm{bp}$ of the trnL-trnF region per isolate. PCR for each sample was performed in a total of $25 \mu \mathrm{l}$ and contained $2.5 \mu \mathrm{l}$ dntp mix, $2.5 \mu \mathrm{MgCl}_{2}, 5 \mu \mathrm{l}$ of Bovine Serum Albumin (New England Biolabs, Ipswich, Massachusetts, USA) $1 \mu \mathrm{l}$ of the forward primer, $1 \mu \mathrm{l}$ of the reverse primer, $0.5 \mu \mathrm{l} \mathrm{Taq}$ (Roche diagnostics, Indianapolis, Indiana, USA), $10.5 \mu$ of $\mathrm{dH}_{2} 0$, and 2 ul of sample DNA. PCRs were run for 37 cycles in a Dyad DNA engine (Bio-Rad Laboratories, Inc., Hercules, California, USA) set to the following parameters: initial denaturation at $94^{\circ} \mathrm{C}$ for $2 \mathrm{~min}$, denaturation at $94^{\circ} \mathrm{C}$ for $1 \mathrm{~min}$, annealing at $55^{\circ} \mathrm{C}$ for $1 \mathrm{~min}$, extension at $72^{\circ} \mathrm{C}$ for $1 \mathrm{~min}$, then final extension at $74^{\circ} \mathrm{C}$ for $7 \mathrm{~min}$ followed by a cool down stage at $4^{\circ} \mathrm{C}$. The amplicon was purified using a Nucleofast 96 well PCR plate (Macherey-Nagel, Evanton, Pennsylvania, USA). Cycle sequencing was performed using the same primer sets as for the PCRs. Sequencing reactions were done using the BigDye terminator cycle sequencing kit (Applied Biosystems, Foster City, California, USA) and amplicons were run on an ABI 3730 (Amersham Pharmacia Biotech Inc., Piscataway, New Jersey, USA). A consensus sequence was constructed and edited using Sequencher version 4.10 (Gene Codes Corp., Ann Arbor, Michigan, USA).

\section{Taxon sampling and outgroup selection}

Initially, the new sequences were compared with GenBank sequences using the BLASTN program (Altschul et al. 1990). The BLAST searches confirmed the position within Frullania subg. Microfrullania. Ingroup taxa representing representatives of this subgenus were selected to test taxonomic hypotheses based on morphology. Several accessions of $F$. rostrata were included because F. knightbridgei shares several morphological characters with this morphologically rather variable taxon. Based on the analyses of Hentschel et al. (2009), three representatives of $F$. subg. Thyopsiella [F. asagrayana Mont., F. microphylla (Gottsche) Pearson, F. tamarisci (L.) Dumort.] were designated as outgroup taxa for phylogenetic reconstruction. Taxa studied, including GenBank accession numbers and voucher details, are listed in Table 1.

\section{Phylogenetic analyses}

All sequences were aligned manually in Bioedit version 7.0.5.2 (Hall 1999). Ambiguous positions were excluded from the alignment and lacking parts of sequences were coded as missing. Maximum parsimony (MP) and maximum likelihood (ML) analyses were carried out with PAUP* version 4.0b10 (Swofford 2000). 
Table I. Frullania taxa used in the present study, including information about the origin of the studied material, voucher information, and the herbarium where the voucher is deposited, as well as GenBank accession numbers. Sequences in bold were obtained from GenBank.

\begin{tabular}{|c|c|c|c|c|}
\hline \multirow[t]{2}{*}{ Taxon } & \multirow{2}{*}{ Origin } & \multirow{2}{*}{ Voucher } & \multicolumn{2}{|c|}{$\begin{array}{l}\text { GenBank accession } \\
\text { number }\end{array}$} \\
\hline & & & ITS2 & $\operatorname{Tr} n \mathrm{~L}-t r n \mathrm{~F}$ \\
\hline F. asagrayana & U.S.A. & Davison 6912 & FJ380498 & FJ380344 \\
\hline $\begin{array}{l}\text { F. knightbridgei von Konrat } \\
\text { \& de Lange }\end{array}$ & $\begin{array}{l}\text { Stewart Island, New } \\
\text { Zealand }\end{array}$ & $\begin{array}{l}\text { von Konrat 99/12-09 } \\
\text { (AK) }\end{array}$ & JQ283996 & JQ284003 \\
\hline $\begin{array}{l}\text { F. lobulata (Hook.) Hook. } \\
\& \text { Nees }\end{array}$ & Chile & Buck 39518 (GOET) & FJ380305 & FJ380465 \\
\hline $\begin{array}{l}\text { F. magellanica F. Weber \& } \\
\text { Nees }\end{array}$ & Chile & Engel 25265 (GOET) & FJ380464 & FJ380304 \\
\hline F. microcaulis Gola & Chile & Engel $25351(\mathrm{GOET})$ & FJ380466 & FJ380306 \\
\hline $\begin{array}{l}\text { F. microphylla (Gottsche) } \\
\text { Pearson }\end{array}$ & Tenerife & $\begin{array}{l}\text { Eckstein } 2287 \\
(\text { GOET) }\end{array}$ & FJ380512 & FJ380358 \\
\hline F. parhamii R.M. Schust. & Fiji & $\begin{array}{l}\text { von Konrat 6/14-27 } \\
\text { (GOET) }\end{array}$ & FJ380463 & FJ380303 \\
\hline $\begin{array}{l}\text { F. rostrata (Hook.f. \& } \\
\text { Taylor) Hook.f. \& Taylor ex } \\
\text { Gottsche et al. }\end{array}$ & $\begin{array}{l}\text { South Island (I), } \\
\text { New Zealand }\end{array}$ & $\begin{array}{l}\text { Engel \& von Konrat } \\
27369 \text { (GOET) }\end{array}$ & FJ380461 & FJ380301 \\
\hline F. rostrata & $\begin{array}{l}\text { South Island (II), } \\
\text { New Zealand }\end{array}$ & $\begin{array}{l}\text { Schäfer-Verwimp } \\
\text { \& Verwimp } 13897 \\
\text { (GOET) }\end{array}$ & FJ380462 & FJ380302 \\
\hline F. rostrata & $\begin{array}{l}\text { Motukowhai Island, } \\
\text { New Zealand }\end{array}$ & Cameron 12503 (AK) & JQ283999 & JQ284006 \\
\hline F. rostrata & $\begin{array}{l}\text { Raoul Island (I), } \\
\text { Kermadec Islands }\end{array}$ & Stanley s.n. (AK) & JQ284000 & JQ284007 \\
\hline F. rostrata & $\begin{array}{l}\text { Raoul Island (II), } \\
\text { Kermadec Islands }\end{array}$ & $\begin{array}{l}\text { de Lange \& Havell } \\
\text { K376 (AK) }\end{array}$ & JQ284001 & JQ284008 \\
\hline F. rostrata & $\begin{array}{l}\text { North Cape (I), } \\
\text { New Zealand }\end{array}$ & de Lange 8034 (AK) & JQ283997 & JQ284004 \\
\hline F. rostrata & $\begin{array}{l}\text { North Cape (II), } \\
\text { New Zealand }\end{array}$ & de Lange 8037 (AK) & JQ283998 & JQ284005 \\
\hline F. sp. & $\begin{array}{l}\text { North Cape, New } \\
\text { Zealand }\end{array}$ & de Lange 8038 (AK) & JQ284002 & JQ284009 \\
\hline F. tamarisci & Germany & Hentschel Bryo0733 & FJ380502 & FJ380348 \\
\hline
\end{tabular}

MP heuristic searches were conducted with the following options: heuristic search mode, 1.000 random-addition-sequence replicates, tree bisection-reconnection (TBR) branch swapping, MULTrees option on, and collapse zero-length branches off. All characters were treated as equally weighted and unordered. Non-parametric bootstrapping values (Felsenstein 1985) were generated as heuristic searches with 1.000 replicates, each with ten random-addition replicates. The number of rearrangements was restricted to ten million per replicate. Bootstrap percentage values (BP) above 70 were regarded as good support (Hillis and Bull, 1993). Where more than one most parsimonious tree was found, trees were summarised in a strict consensus tree. 
The two genomic regions were first analysed separately to check for incongruence. The strict consensus trees of the non-parametric bootstrap analyses were compared by eye to identify conflicting nodes supported by at least 70\% (Mason-Gamer and Kellog 1996). The trees gave no evidence of incongruence. Hence the datasets were combined. jModeltest 0.1 (Posada 2008) was used to select the TIM2 + G model of evolution for the ML analysis of the combined dataset. The analysis was performed as heuristic search using ten random-sequence addition replicates, MULTrees option on, collapse zero length branches off, and TBR branch swapping. The confidence of branching was assessed with PAUP* using 200 non-parametric bootstrap resamplings generated as heuristic searches.

\section{Species concept}

Although the determination of species is regarded as one of the most important activities of the taxonomist, the majority of systematists undertaking monographs and revisions of vascular plants do not discuss the concepts or the criteria to delimit species (McDade 1995). A similar statement can undoubtedly be applied to liverwort systematics (von Konrat et al. 2006a, 2010). Here, we adopt a hierarchical model as promoted by Mayden (1997). This model considers the Evolutionary Species Concept as a theoretically robust primary species concept, as well as a bridging, secondary or operational species concept. This is discussed in the context of Frullania by von Konrat et al. (2006a).

\section{Data resources}

The occurrence data underpinning the analysis has been uploaded as a Darwin Core Archive (DwC-A), to the Global Biodiversity Information Facility (GBIF) via the Pensoft Data Hosting Center at the GBIF's Integrated Publishing Toolkit (IPT) (http://ipt.pensoft.net/ipt/manage/resource.do?r=deep_south_frullania_species). The genomic sequences are deposited at GenBank and their hyperlinked accession numbers are listed in Table 1.

In addition to the current paper semantically tagged and enhanced using the Pensoft Mark Up Tool (PMT), repository data and images, including images with zoom capability can also be accessed at www.discoverlife.org and www.symbiota.org for selected species that are closely allied to the newly described species. The Consortium of North American Bryophyte Herbaria $(\mathrm{CNABH})$ was created to serve as a gateway to distribute data resources of interest to the taxonomic and environmental research community, offering a common web interface, including tools to locate, access and work with a variety of data (see http://symbiota.org/bryophytes/index.php).

Frullania rostrata can be accessed at the following urls: http://www.discoverlife.org/mp/20q?search=Frullania+rostrata 
http://symbiota.org/bryophytes/taxa/index.php?taxon=Frullania\%20rostrata http://symbiota.org/bryophytes/taxa/index.php?taxon=166175

http://emuweb.fieldmuseum.org/botany/botanytaxDisplay.php?irn=93741

Frullania magellanica can be accessed at the following url's:

http://www.discoverlife.org/mp/20q?search=Frullania+magellanica

http://symbiota.org/bryophytes/taxa/index.php?taxon=166024

Frullania truncatistyla can be accessed at the following url:

http://symbiota.org/bryophytes/taxa/index.php?taxon=232649

\section{Results and discussion}

In the present study, hypotheses of species differences are based on support from multiple lines of evidence, including morphology, experimental growth studies, and nucleotide sequences. This is discussed below.

\section{Phylogeny}

Of a total of 964 molecular characters, 127 were parsimony informative, 62 autapomorphic, and 775 constant (Table 2). The MP analysis resulted in two trees of 304 steps with a consistency index of 0.78 and a retention index of 0.80 (not depicted). A single most likely tree was found in the ML analysis (Fig. 1, ln = -2984.6458). MP and ML topologies differ only slightly. In the MP topology, $F$. parhamii R.M.Schust. is placed in a polytomy with the F. rostrata (Hook.f. \& Taylor) Hook.f. \& Taylor ex Gottsche, Lindenb. \& Nees representatives whereas in the ML trees, F parhamii is placed sister to Frullania rostrata in an unsupported relationship. Frullania knightbridgei is well separated from Frullania rostrata, and placed in a paraphyletic grade with other members of $F$. subg. Microfrullania. The morphologically similar F. truncatistyla von Konrat, Hentschel, Heinrichs \& Braggins has not yet been included in molecular studies.

Table 2. Distribution of constant and phylogenetically informative sites for aligned positions of the two genomic regions.

\begin{tabular}{l|c|c|c}
\hline & L-Ftrn & ITS1-5.8S-ITS2 & Total \\
\hline $\begin{array}{l}\text { Number of sites in } \\
\text { matrix }\end{array}$ & 516 & 448 & 964 \\
\hline constant & 465 & 310 & 775 \\
\hline autapomorphic & 28 & 34 & 62 \\
\hline parsimony informative & 23 & 104 & 127 \\
\hline
\end{tabular}




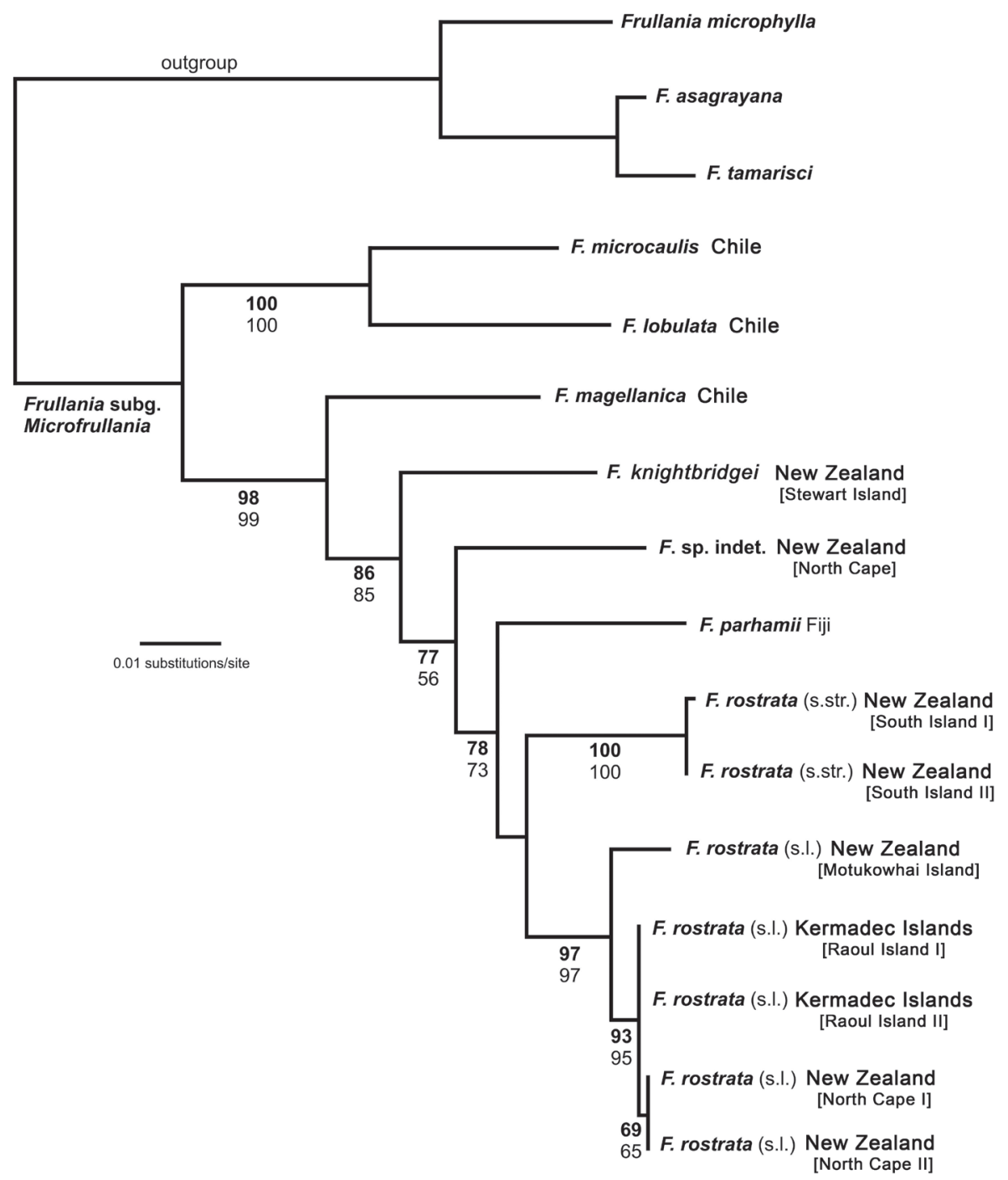

Figure I. Maximum likelihood phylogeny $(\mathrm{ln}=-2984.6458)$ derived from an nrITS2 - trnL-F sequence alignment including 14 new sequences and 18 sequences from Hentschel et al. (2009). ML bootstrap percentage values (> 50) in bold face, MP bootstrap percentage values (>50) not bold.

Frullania rostrata is split in two robust subclades. Hence, the ML phylogeny indicates that $F$. rostrata - despite exclusion of $F$. knightbridgei - is part of a species complex, possibly with some geographical structure. This may be supported by the significant number of synonyms and herbarium specimens summarised under F. rostrata (von Konrat et al. 2006a). Frullania rostrata might well be regarded as a Southern Hemisphere equivalent of the Holarctic Frullania tamarisci. Heinrichs et al. (2010) investigated F. tamarisci, which is typically regarded as a single polymorphic species. Using sequences from the nrITS 
region and plastid $\operatorname{trn} \mathrm{L}-t r n \mathrm{~F}$ and $a t p \mathrm{~B}-r b c \mathrm{~L}$, their analyses resolved eight partly sympatric monophyletic groups representing distinct species rather than subspecies or varieties.

The number of molecular studies at the population level in liverworts is still limited. This hampers our efforts to quantify the contribution of cryptic species to the global biodiversity of liverworts (von Konrat et al. 2010). Existing studies suggest a significant part of bryophyte biodiversity is undetected with traditional morphological concepts alone (Heinrichs et al. 2009). It is clear, we urgently need more species-level phylogenies with extensive population sampling to approximate the actual diversity of Frullania, and to elucidate speciation processes and distribution range formation (Bombosch et al. 2010, Heinrichs et al. 2010, Ramaiya et al. 2010).

\section{Growth studies}

In Frullania, as well as liverworts generally, there remains a large gap between characters used for delimitation and our understanding and knowledge of their plasticity in nature (von Konrat et al. 2006b). Frullania rostrata and the new species, $F$. knightbridgei, responded well to growing in controlled environmental conditions in a glasshouse unit. Oil bodies in particular were monitored. The stability of oil body characters indicates that the differences have some underlying genetic basis; thus it is likely that the salient characters of this species are genetically dependent rather than influenced by the environment.

\section{Morphology}

Many critical morphological features have often been neglected in liverwort systematics (Schuster 1992; von Konrat et al. 1999, 2001a, 2006b), and scores of studies have been restricted to herbarium material where ephemeral structures; e.g., sporophytes and oil bodies, have not been available (von Konrat et al. 2006a,b; Heinrichs et al. 2009). The new species is morphologically aligned to a group of species representing $F$. subg. Microfrullania, which has been resolved as a monophyletic group (Hentschel et al. 2009). Inclusion of F. knightbridgei in F. subg. Microfrullania is also supported by molecular evidence as discussed above. Frullania subg. Microfrullania represents a clade with the most historical confusion out of all Frullania subgenera with taxa occurring in southern South America, Australasia and islands of the South Pacific, New Guinea, and Indonesia (von Konrat et al. 2006a, 2010).

The new species appears almost to lie intermediate between F. rostrata, of New Zealand and Australia, and F. pseudomeyeniana S. Hatt. of New Caledonia. The latter is only known from the type material (New Caledonia, Mont Mou, N of Paita, 1100 m., Kitagawa 21422, NICH), which was examined by the senior author. Frullania knightbridgei also has some similarity with $F$. magellanica (Spreng.) F. Weber et Nees of Chile. Frullania knightbridgei superficially strongly resembles some forms of F. rostrata in plant 

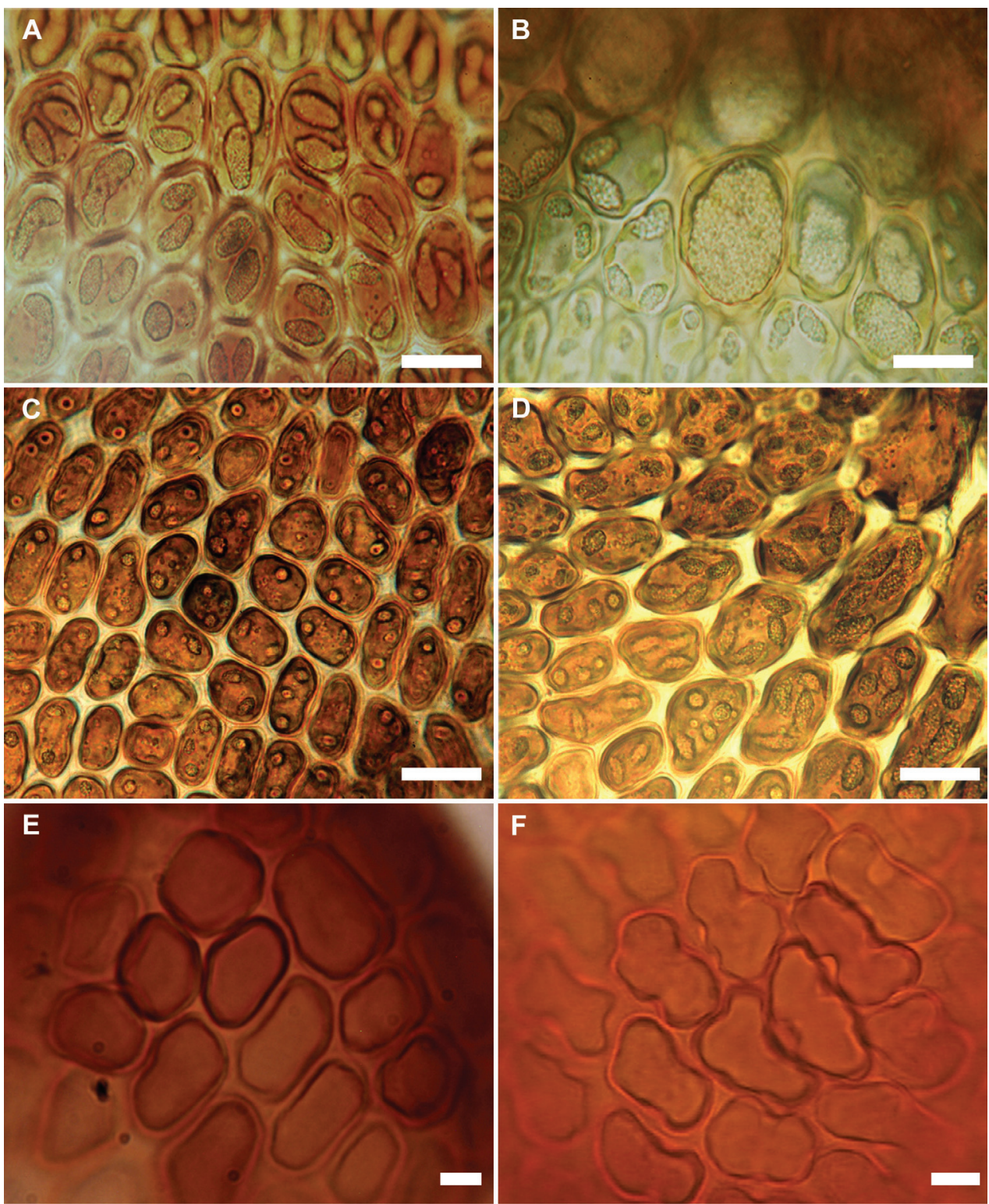

Figure 2. Variation in characters associated with the leaf-lobe oil bodies and leaf-lobule anatomy $(\mathbf{A}, \mathbf{B}$, E Frullania knightbridgei; C, D, $\mathbf{F}$ Frullania rostrata) $\mathbf{A}$ Oil bodies of the median region of the leaf-lobe, very large, (1)2-(3) per cell, collectively occupying over $75 \%$ of the cell lumen B Oil bodies of basal cells, a characteristic group of basal ocelli, each ocellus almost occupying the entire cell lumen $\mathbf{C}$ Oil bodies of median cells, 2-3 per cell, collectively occupying very small area of cell lumen, lacking any significant ornamentation and appearing as almost homogeneous oil droplets D Oil bodies of basal cells, 3-5 per cell E Semi straight cell walls toward apex leaf-lobule $\mathbf{F}$ Flexuose cell walls towards apex of leaf lobule. Scale bars $\mathrm{A}, \mathrm{B}=15 \mu \mathrm{m} ; \mathrm{C}-\mathrm{F}=10 \mu \mathrm{m}$. 
size, the large styli and lobules, and the entire underleaves. However, with fresh material, F. knightbridgei is immediately discernable from $F$. rostrata by the presence of large oil bodies (usually only 2 per cell, occasionally 1 or 3 ) that almost occupy the entire cell lumen of basal and median cells of the leaf lobe (Fig. 2a-b). In the absence of oil body data, careful consideration has to be given to the anatomy of the leaf-lobe and -lobule to help differentiate between these species. In F. knightbridgei, cells towards the lobule apex progressively develop a more regular shape (quadrate to rectangular) and the cell walls become semi-straight (Fig. 2e). Conversely, the cell walls of both $F$. rostrata and $F$. pseudomeyeniana are flexuose with indistinct trigones, and with small, nodulose intermediate thickenings throughout the lobule, from the base to the apex (Fig. 2f).

The unique cell anatomy of the leaf lobe in F. knightbridgei further places it into an isolated position within subg. Microfrullania; this species is seemingly unique in having a group of conspicuously enlarged cells, originating from the base of the lobe and extending 10-14 cells out toward the apex, forming a partial band or pseudo vitta up to 4-6 cells wide (Fig. 3). The cells are enlarged to accommodate the typically 2 large oil bodies. The features of the oil bodies are unique within $F$. subg. Microfrullania. In those species examined thus far, the oil bodies of the leaf lobe median cells number from 2-4(5) per cell, are of small size and lack any significant ornamentation, almost appearing as homogeneous oil droplets (von Konrat et al. 2006a, 2010) (Fig. 2c-d).

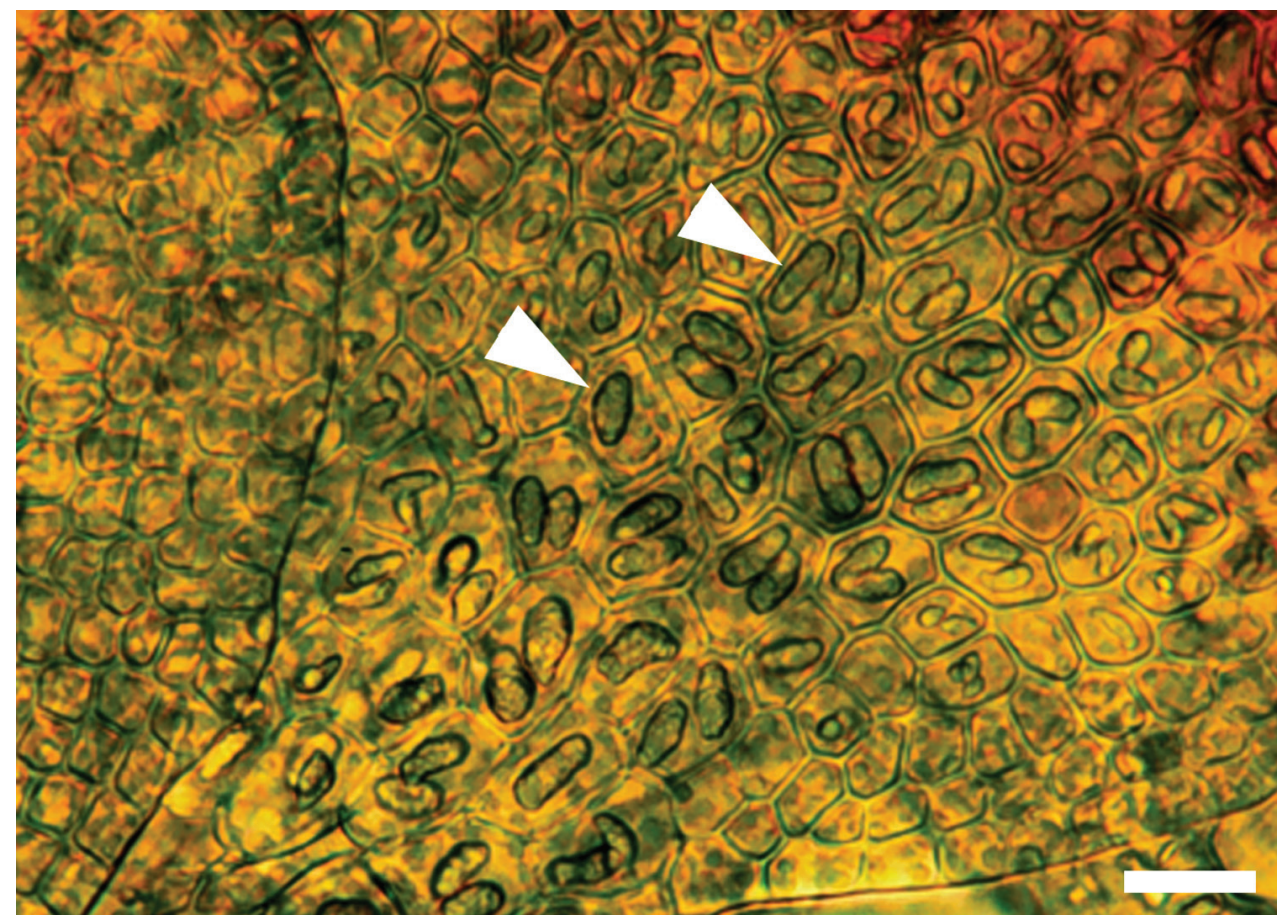

Figure 3. Oil bodies in a leaf shoot of Frullania knightbridgei illustrating, in region of arrow, the 1-2 large oil bodies per cell. Scale bar $=20 \mu \mathrm{m}$. 
The position of the lobules in relation to the stem as well as styli shape and form are often used to help distinguish between taxonomic units of varying levels in Frullania taxonomy. Lobule position varies in F. knightbridgei, ranging from parallel to subparallel with the stem or with the lobule spreading at a strong angle, so that the lobuli are tilted inwards. Frullania pseudomeyeniana and some phenotypes of F. rostrata also have lobuli that lie almost parallel or subparallel to the stem for both species. Frullania magellanica also has at least some phases with lobules more or less parallel to the stem (Engel 1978). Interestingly, the parallel lobule position is typically a feature associated with species of subg. Thyopsiella. Thus lobule position must be used secondary to and in collaboration with more salient characters in circumscribing $F$. subg. Microfrullania.

Historically, characters associated with the capsule wall and spore surface ultrastructure have rarely been utilized in Frullania systematics (von Konrat et al. 2006b). Yet, it is clear that characters associated with these structures have great utility at various taxonomic levels (e.g., von Konrat et al. 1999, 2006b, 2010). The spores of F. knightbridgei have a "rosette" with conspicuous protuberances lacking secondary branches and deposits - a feature used to help characterize F. subg. Microfrullania (Hentschel et al. 2009). The spores can also be used to distinguish Frullania knightbridgei and F. rostrata (Table 3, Fig. 5). Differences are also reflected in the epidermal wall of the capsule. In F. knightbridgei, the walls are nodular, where the lobes extend irregularly for a
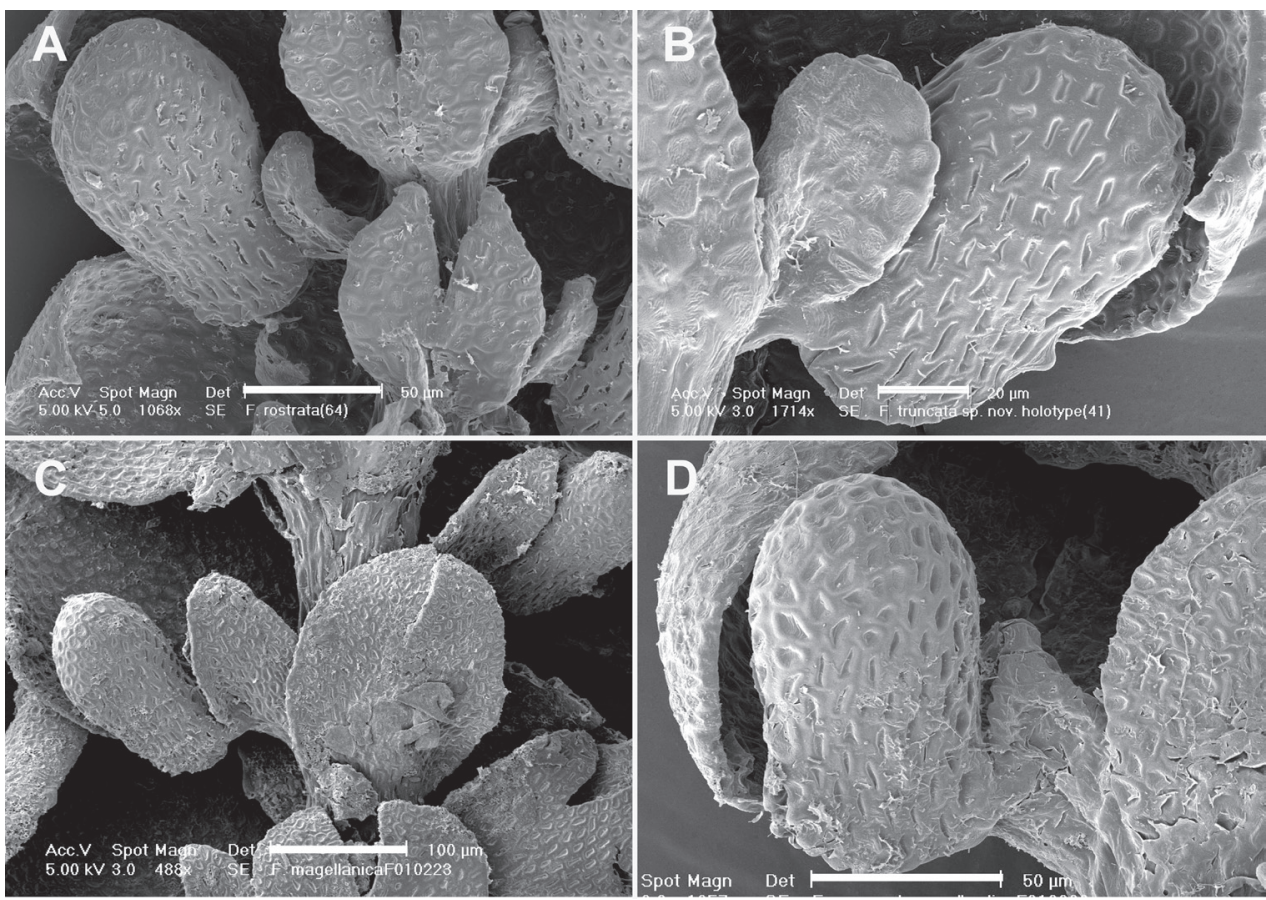

Figure 4. Lobule position and styli. A Frullania rostrata B Frullania truncatistyla C Frullania magellanica D Frullania knightbridgei Scale bars A, D = $50 \mu \mathrm{m} ; \mathrm{B}=20 \mu \mathrm{m} ; \mathrm{C}=100 \mu \mathrm{m}$. 
short distance over the tangential face toward the centre of the cell and have intermediate thickenings near the middle of the longer walls (Fig. 5a). In F. rostrata, the lobes extend toward the centre of the tangential face for a short distance, as short rounded or obtuse lobes and the juxtaposed corner thickenings form 3-4 lobed figures; intermediate thickenings are also lacking (Fig. 5b).

Tables 3-5 summarizes the characters differentiating F. knightbridgei from two morphologically similar species that it might be confused within the New Zealand bo-
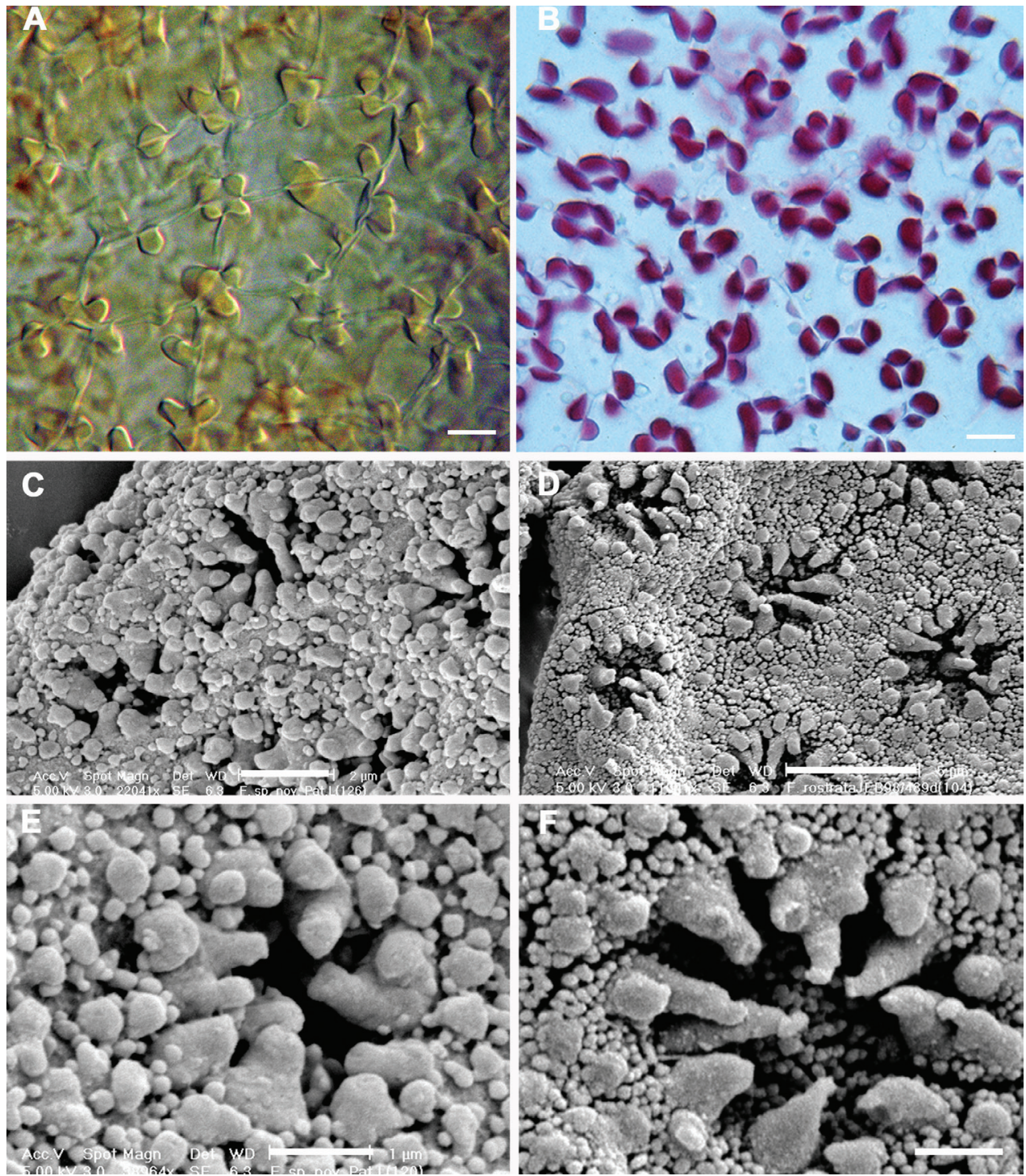

Figure 5. Epidermal layer of the capsule wall and spore surface ultrastructure. A Epidermal layer of Frullania knightbridgei B Epidermal layer of Frullania rostrata C, E Spore surface of Frullania knightbridgei D, F Spore surface of Frullania rostrata. Scale bars A, B $=10 \mu \mathrm{m} ; C=2 \mu \mathrm{m} ; \mathrm{D}=5 \mu \mathrm{m} ; \mathrm{E}, \mathrm{F}=1 \mu \mathrm{m}$. 
Table 3. Initial branching appendages.

\begin{tabular}{l|l|l|l}
\hline Branching & F. knightbridgei & F. truncatistyla & F. rostrata \\
\hline Branching type & Frullania-type & $\begin{array}{l}\text { Usually Frullania-type, } \\
\text { occasionally Lejeunea- } \\
\text { type }\end{array}$ & $\begin{array}{l}\text { Usually Frullania-type, } \\
\text { occasionally Lejeunea-type }\end{array}$ \\
\hline $\begin{array}{l}\text { First branch } \\
\text { underleaf (BUL1) }\end{array}$ & $\begin{array}{l}\text { 1 ventral, explanate, } \\
\text { bilobed segment }+1 \\
\text { dorsal saccate segment }\end{array}$ & $\begin{array}{l}\text { 1 ventral, explanate, } \\
\text { bilobed segment + 1 } \\
\text { dorsal saccate segment }\end{array}$ & $\begin{array}{l}\text { 1 ventral, explanate, bilobed } \\
\text { segment + 1 dorsal saccate } \\
\text { segment }\end{array}$ \\
\hline $\begin{array}{l}\text { First branch leaf } \\
\text { (BL1) initial } \\
\text { appendages }\end{array}$ & $\begin{array}{l} \pm \text { characteristic of } \\
\text { normal stem leaves }\end{array}$ & $\begin{array}{l}\text { Variable, either elobulate, } \\
\text { and explanate to sulcate, } \\
\text { or } \pm \text { characteristic of } \\
\text { normal stem leaves }\end{array}$ & $\begin{array}{l}\text { Variable, either elobulate, } \\
\text { and explanate to sulcate, or } \\
\pm \text { characteristic of normal } \\
\text { stem leaves }\end{array}$ \\
\hline
\end{tabular}

Table 4. A comparison of morphological characters between three New Zealand species, F. knightbridgei, F. truncatistyla and F. rostrata.

\begin{tabular}{|c|c|c|c|}
\hline Character & F. knightbridgei & F. truncatistyla & F. rostrata \\
\hline Shoot width & To $\mu \mathrm{m} 1000 \mu \mathrm{m}$ & To $550 \mu \mathrm{m}$ & To $1100 \mu \mathrm{m}$ \\
\hline \multicolumn{4}{|l|}{ Stem } \\
\hline Cortical cells & $10-34$ & $7-12$ & $10-25$ \\
\hline Medullary cells & $12-28$ & $8-14$ & $12-30$ \\
\hline \multicolumn{4}{|l|}{ Leaf-lobe } \\
\hline Apex & Rounded & Acute & $\begin{array}{l}\text { Rounded to sharply } \\
\text { acute }\end{array}$ \\
\hline Median cell size & $\begin{array}{l}\text { Dimorphic; central band } \\
\text { of cells similar to basal } \\
\text { cells }\end{array}$ & $\begin{array}{l}\text { Markedly uniform and } \\
\text { smaller than basal cells }\end{array}$ & $\begin{array}{l}\text { Markedly uniform and } \\
\text { smaller than basal cells }\end{array}$ \\
\hline \multicolumn{4}{|l|}{ Leaf-lobule } \\
\hline $\begin{array}{l}\text { Position in relation } \\
\text { to stem }\end{array}$ & $\begin{array}{l}\text { Often almost parallel } \\
\text { with the stem, or at most } \\
\text { lobules at angles of up to } \\
\text { ca. } 25^{\circ}\end{array}$ & $\begin{array}{l}\text { Angles of } 30-50(60) \\
\text { u with the stem so that } \\
\text { lobules tilted outwards }\end{array}$ & $\begin{array}{l}\text { 20) } 30-50(60)^{\circ} \text { with } \\
\text { the stem so that lobules } \\
\text { tilted outwards }\end{array}$ \\
\hline Length:width ratio & $1.75-2: 1$ & 1.0-2.0:1 & $1.5-2.25: 1$ \\
\hline $\begin{array}{l}\text { No. of cells in } \\
\text { circumference }\end{array}$ & To 25 & To 20 & To 28 \\
\hline Colour & Bicoloured & $\begin{array}{l}\text { Uniform colour similar to } \\
\text { other organs }\end{array}$ & $\begin{array}{l}\text { Uniform colour similar } \\
\text { to other organs }\end{array}$ \\
\hline $\begin{array}{l}\text { Cell walls toward } \\
\text { lobule apex }\end{array}$ & Semi straight & Flexuose & Flexuose \\
\hline \multicolumn{4}{|l|}{ Stem-underleaf } \\
\hline Margin & Entire & Entire & $\begin{array}{l}\text { Entire; occ. angulated or } \\
\text { toothed. }\end{array}$ \\
\hline \multicolumn{4}{|l|}{$\begin{array}{l}\text { No. of cells wide } \\
\text { (lobe) }\end{array}$} \\
\hline $\begin{array}{l}\text { Width in } \\
\text { comparison to stem }\end{array}$ & (2) $2.5-3.5(4)$ & $1.0-1.25$ & (1) $2-3.5$ (5) \\
\hline \multicolumn{4}{|l|}{ Stylus } \\
\hline Shape & \pm triangular & $\begin{array}{l}\text { Subrectangular, apex } \pm \\
\text { truncate to subtruncate }\end{array}$ & $\begin{array}{l}\text { Variable, subtriangular } \\
\text { to foliaceous to sickle- } \\
\text { shaped }\end{array}$ \\
\hline
\end{tabular}




\begin{tabular}{l|l|l|l}
\hline Character & F knightbridgei & F. truncatistyla & F. rostrata \\
\hline Sexuality & Dioecious & Dioecious & Dioecious \\
\hline Archegonia No. & 1 & 1 & $1-2$ \\
\hline Perianth & Plicate, to 6-keeled & 3-keeled & $3-5$ keeled \\
\hline Spores & \multicolumn{2}{l}{} \\
\hline $\begin{array}{l}\text { Form of projections } \\
\text { comprising rosette }\end{array}$ & $\begin{array}{l}\text { Taper gradually to a } \\
\text { rounded or truncate apex }\end{array}$ & Not seen & $\begin{array}{l}\text { Taper gradually to a } \\
\text { rounded or subacute, } \\
\text { often hooked apex }\end{array}$ \\
\hline
\end{tabular}

Table 5. Characters associated with oil bodies of the leaf-lobe.

\begin{tabular}{|c|c|c|c|c|}
\hline Character & \multicolumn{2}{|c|}{ F. knightbridgei } & F. truncatistyla & F. rostrata \\
\hline \multirow[t]{2}{*}{ General } & \multicolumn{2}{|c|}{ Dimorphic } & Monomorphic & Monomorphic \\
\hline & Type 1 & Type 2 & & \\
\hline \multicolumn{5}{|l|}{ Median cells } \\
\hline Size & $\begin{array}{c}\text { (2) } 3-7(9) \mu \mathrm{m} \text { in } \\
\text { diam. to (5) } 6-11 \\
(13) \times(4) 5-10 \\
(12) \mu \mathrm{m}\end{array}$ & $\begin{array}{c}\text { (1) } 2-4(5) \mu \mathrm{m} \text { in } \\
\text { diam. to (2) } 3-5 \\
\text { (6) } \mu \mathrm{m} \times(1) 2-3 \\
\text { (4) } \mu \mathrm{m}\end{array}$ & $\begin{array}{c}\text { (1) } 2-3(4) \mu \mathrm{m} \text { to } \\
\text { (2) } 2-3(5) 3(1) \\
1-2(3) \mu \mathrm{m}\end{array}$ & $\begin{array}{l}\text { (1) } 2-3(4) \mu \mathrm{m} \text { in } \\
\text { diam. to (2) } 3-5(6) \\
\mu \mathrm{m} \times(1) 2-3(4) \mu \mathrm{m}\end{array}$ \\
\hline Shape & $\begin{array}{c}\text { Rarely subspherical } \\
\text { usually ovoid or } \\
\text { ellipsoidal }\end{array}$ & $\begin{array}{l}\text { Spherical to ovoid } \\
\text { or ellipsoidal }\end{array}$ & $\begin{array}{l}\text { Spherical to ovoid } \\
\text { or ellipsoidal }\end{array}$ & $\begin{array}{l}\text { Spherical to ovoid or } \\
\text { ellipsoidal }\end{array}$ \\
\hline Number & $1-2$ & $2-3(4)$ & $2-3(4)$ & $2-3(5)$ \\
\hline $\begin{array}{l}\text { Density } \\
\text { (collectively) }\end{array}$ & $\begin{array}{l}\text { Occupying almost } \\
\text { entire cell lumen }\end{array}$ & $\begin{array}{l}\text { Occupying }<25 \% \\
\text { of cell lumen }\end{array}$ & $\begin{array}{l}\text { Occupying <25\% } \\
\text { of cell lumen }\end{array}$ & $\begin{array}{c}\text { Occupying }<25 \% \text { of } \\
\text { cell lumen }\end{array}$ \\
\hline Surface & Appearing granular & $\begin{array}{c}\text { Appearing } \pm \\
\text { homogeneous }\end{array}$ & $\begin{array}{c}\text { Appearing } \pm \\
\text { homogeneous }\end{array}$ & $\begin{array}{c}\text { Appearing } \pm \\
\text { homogeneous }\end{array}$ \\
\hline \multicolumn{5}{|l|}{ Basal cells } \\
\hline Number & $1-2$ & & $3-5$ & (2) $3-5(6)$ \\
\hline
\end{tabular}

tanical region - Frullania truncatistyla and F. rostrata. This includes critical characters associated with initial branching appendages (Table 3), oil bodies and cell anatomy (Table 5, Fig. 2,3), stem anatomy, leaf lobe, underleaf, leaf lobule and stylus (Table 4, Fig. 4), perianth, and sporophyte, including spores (Table 4, Fig. 5).

\section{Taxonomic treatment}

Artificial key distinguishing Frullania knightbridgei from morphologically allied species of subg. Microfrullania, including those distributed in New Zealand.

Fertile and sterile features combined

1 Leaf-lobes with denticulate to coarsely dentate margins Sect. Microfrullania: Frullania chevalieri, F. microscopica, F. parhamii [incl. New Zealand, New Caledonia, and Fiji]

- $\quad$ Leaf-lobes with entire margins, lacking any form of marginal dentition .......2 
2 Stylus a distinct, obovate to subrectangular in shape with a truncate apex; a distinctive angular projection on the lobule immediately above the slit; plants small (c. 250-500 $\mu \mathrm{m})$.

.F. truncatistyla [North Island, South Island, Stewart Island]

- Styli sickle-shaped, subtriangular to triangular; distinctive angular projection absent (not to be confused with the \pm discoloured, gibbous, cell above mouth); plants small to medium ................................................................. 3

3 Dioecious, gynoecia terminal on leading stems with subfloral systems (i.e., subfloral innovations or subfloral branches); stylus small to medium, 0.25$0.5 \times$ the length of the lobule), typically stylus with up to $10-35$ cells .........4

- $\quad$ Monoecious, gynoecia on short lateral branches lacking subfloral systems; stylus typically large, $0.75-1.0 \times$ the length of the lobule, stylus with up to 100 cells total. F. magellanica [Chile]

4 Lobules typically at an angle in relation to the stem, leaf-lobe median cells smaller than basal cells and with 3-4 oil bodies per cell, occupying $<50 \%$ of the area of the cell lumen; perianth typically 3 -keeled

F. rostrata s. 1. [Australasia]

- $\quad$ Lobuli varied, typically subparallel to the stem; a band (pseudovitta) of median cells (of leaf-lobe) as large as basal cells and with $1-2$ oil bodies per cell, occupying almost entire cell lumen (where known); perianth plicate 5-6 keeled

5 Leaf lobes often squarrose; main stem underleaves small, \pm as wide as stem; leaf lobule clavate, cell walls distinctly flexuose toward the lobule apex

F. pseudomeyeniana [New Caledonia]

- $\quad$ Leaf lobes flat, not squarrose; main stem underleaves medium to large, wider than stem; leaf lobule cylindrically helmet-shaped, cell walls becoming distinctly semi-straight toward lobule apex

.F. knightbridgei [Stewart Island, Auckland Island]

\section{Frullania knightbridgei von Konrat \& de Lange, sp. nov.}

http://species-id.net/wiki/Frullania_knightbridgei

Figs 2-7

Diagnosis. Frullania knightbridgei is similar to F. rostrata (Hook.f. \& Taylor) Hook.f. \& Taylor ex Gottsche et al., but differing by the presence of large oil bodies that occupy almost the entire lumen of the basal and median cells of the leaf lobe, and the often bicoloured lobules, which usually lie almost parallel to the stem. The leaf lobule cell walls of F. knightbridgei are distinctly semi-straight toward the lobule apex whereas in $F$. rostrata the cell walls are distinctly flexuose toward the lobule apex.

Type. New Zealand: Stewart Island: Rakiura/Stewart Island National Park, 500 m. from North Arm Hut, on bark of Dracophyllum longifolium overhanging water on margin of Patterson Inlet, canopy of stunted Dacrydium cupressinum and Metrosideros 


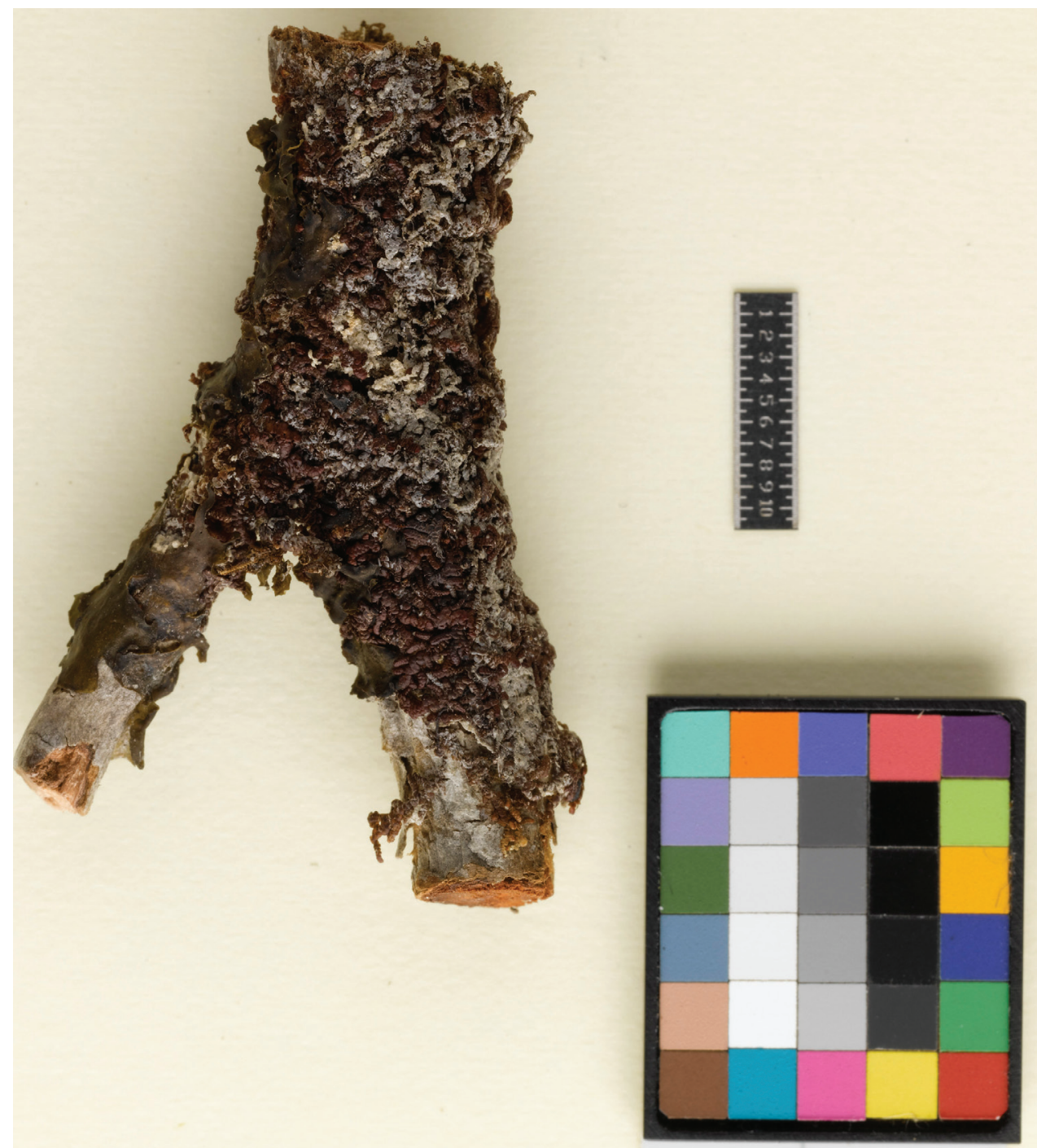

Figure 6. Frullania knightbridgei on twig, Auckland Island. (Coll. Common C893B).

umbellata. Near sea level, 46²5'55"S, 16801'04"E, 12 Dec 1999, M. von Konrat 99/12-09 (holotype AK; isotypes CHR, F).

Description. Plants small to medium (main shoots to $600 \mu \mathrm{m}$ wide), forming olive-green, copper-brown, to black patches, closely to loosely adhering to substrate. Leading stem 15-25 mm long and to $90 \mu \mathrm{m}$ in diameter, 6-9 cells wide, little differentiation between cortical cells (18-24 in no.) and medullary cells (14-28 in no.), the former often slightly smaller than the latter, both with firm walls, lumen irregularly shaped. Branching often regularly pinnate, occasionally bipinnate to rarely tripinnate, branches with progressively smaller leaves; Frullania-type branching. First branch un- 

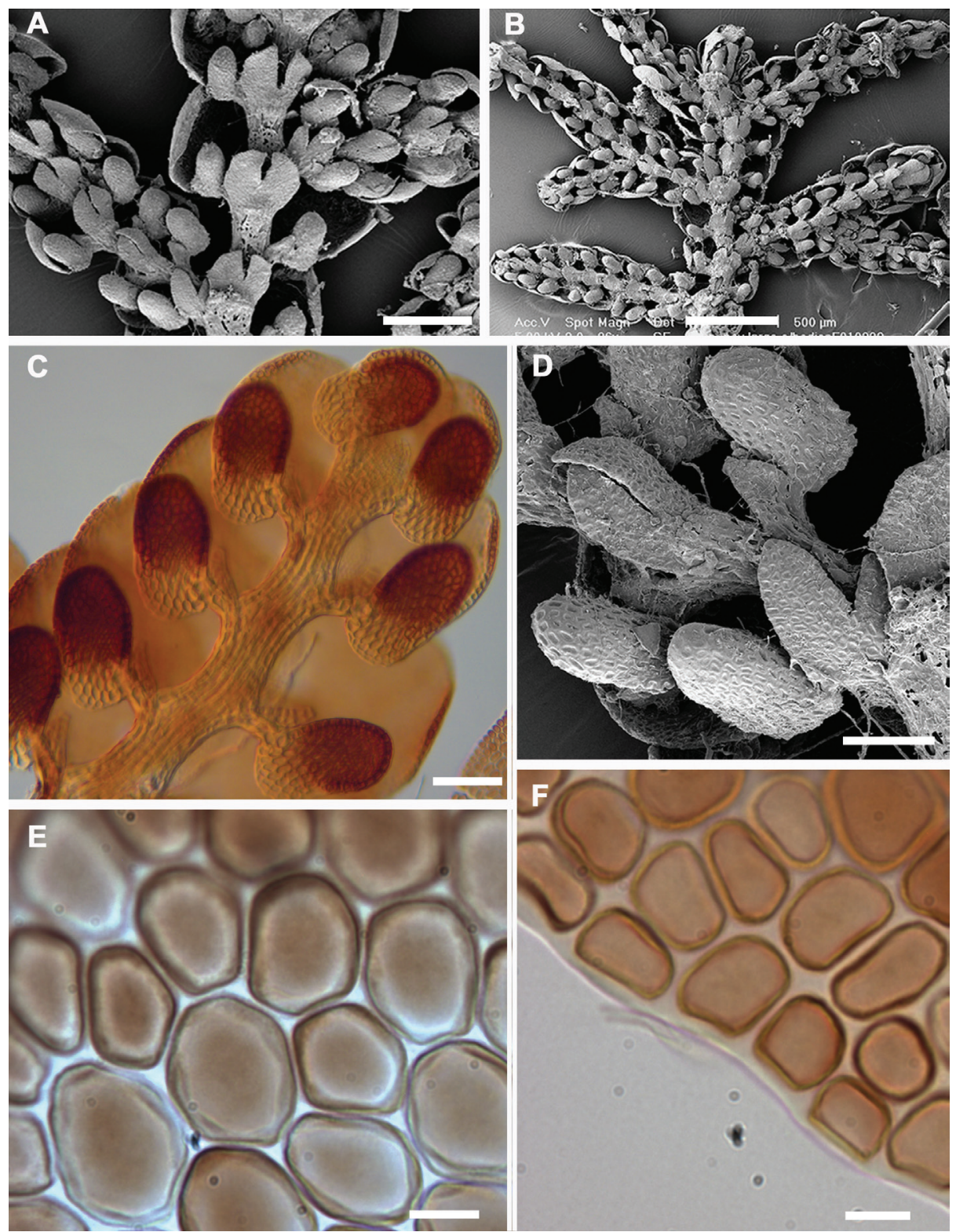

Figure 7. Frullania knightbridgei A, B Main stem, ventral view. A Main stem and lateral branches, lobules subparallel in relation to the stem and occupying ca. $25 \%$ of the exposed surface of the dorsal lobe $\mathbf{B}$ Illustrating terminal position of the gynoecium with 2 subfloral branches immediately below $\mathbf{C}$ Bicoloured leaf-lobules $\mathbf{D}$ Initial branching appendages $\mathbf{E}$ Median cells of the leaf-lobe with subequally thickened cell walls $\mathbf{F}$ Basal cells of the leaf-lobe. Scale bars $A=200 \mu \mathrm{m} ; \mathrm{B}=500 \mu \mathrm{m} ; \mathrm{C}, \mathrm{D}=50 \mu \mathrm{m} ; \mathrm{E}, \mathrm{F}=10 \mu \mathrm{m}$.

derleaf (BUL1) always with three distinct segments, the ventral lamina divided for $1 / 3-2 / 3$ its length into two unequally or subequally sized lobes +1 dorsal saccate lobe; First branch leaf (BL1) usually \pm characteristic of normal stem leaves (i.e. 1 explanate 
dorsal lobe +1 saccate lobule +1 stylus). Stem leaves of main branch flat when dry and wet, slightly imbricate to contiguous, suborbicular to broadly ovate, to $375 \mu \mathrm{m}$ long $\times 350 \mu \mathrm{m}$ wide with incurved distal margins, dorsal margins extending beyond the farther edge of the stem, rounded apices, non-auriculate and \pm subtruncate at the base, entire margins, smooth dorsal surface. Lobules remote from the stem (lobule attached to stem by 3-4 cells) and usually almost parallel with the stem so that the long axis of the lobule is \pm parallel with the main stem (or at most lobules at angles of up to ca. $25^{\circ}$ with the stem so that lobules only very slightly tilted outwards); lobules often bicoloured with the basal 2-5 cells towards the mouth (up to 0.25 of the lobule) hyaline to subhyaline, in contrast to the olive-green to brown pigmentation elsewhere; cylindrically helmet-shaped (orbicular in cross-section with up to 25 cells in circumference); lobules \pm medium (lobule area obscuring no more than $0.25 \times$ the exposed area of the dorsal lobe), ca. 1.75-2 $\times$ long as wide, $110-200 \mu \mathrm{m}$ long $\times 60-100 \mu \mathrm{m}$ wide (up to $12-14$ cells high $\times 6-8$ cells wide); \pm equally inflated throughout (so that the sides of the lobule are \pm parallel), the opening wide, extending only slightly along the abaxial lobule margin; ca. $2 / 3$ from lobule apex there is usually a \pm discoloured, gibbous, cell (the free margin of the cell with a heavily thickened wall); mouth nearest the stylus, truncate at base then cells with septa between adjacent cells \pm swollen, the mouth thus then becoming crenulate-sinuate; lobule usually hyaline near mouth, lobule apex obtuse, surface of lobule smooth. Stylus medium in size $\left(1 / 3^{2} / 3 \times\right.$ the length of the lobule), \pm triangular, up to $60 \mu \mathrm{m}$ long $\times 50 \mu \mathrm{m}$ wide, (4) 5-6 (7) cells wide at base, (10) 12-24 (30) cells in total, occasionally with a poorly developed slime papilla at the apex. Underleaves of leading stems bilobed, obovate to rotundate, at most only contiguous with lobules, underleaves contiguous to distant from each other, usually long as wide, occasionally slightly longer than wide, (2) 2.5-3.5 (4)× the stem in width, to 100-175 $\mu \mathrm{m}$ long $\times 100-150 \mu \mathrm{m}$ wide, broadest at middle, free lateral margins always entire; apex of underleaf bilobed to $1 / 3-1 / 2$ its length, lobes separated by a V-shaped sinus, the lobes 9-14 cells wide at base and with blunt to subacute or rounded apices. Rhizoidinitial area present near base of underleaf, rhizoids often seen, subhyaline, in bundles, to $400 \mu \mathrm{m}$ long. Not strictly microphyllous, lobules of secondary stems \pm similar size to main stem, but lobes and underleaves of secondary branches slightly smaller than those of leading stems.

Leaf-lobe: to 20 cells long, from base to apex, by 35 cells at widest region; with a band of conspicuously enlarged cells originating from the lobe base and extending out towards the lobe apex 10-12 cells, and up to 6 cells wide at the widest region. Lobe marginal cells \pm rectangular to subquadrate, small to $8 \mu \mathrm{m}$ long $\times 6 \mu \mathrm{m}$ wide, hyaline walls subequally thickened, cell cavities brownish red. Cells of the middle region of the lobe are \pm dimorphic in size; Type One [see below]: 4-6 rows of median cells, cells to $30 \mu \mathrm{m}$ long $\times 22.5 \mu \mathrm{m}$ wide (usually $2-2.75 \times$ long as wide), thus similar in size to basal cells; Type Two [see below]: cells gradually becoming reduced in size (median cells to $15 \mu \mathrm{m}$ long $\times 10 \mu \mathrm{m}$ wide, usually $1.25-2 \times$ long as wide, between central band of enlarged cells and lobe margin). Both cell types usually pentagonal or hexagonal, hyaline walls subequally thickened, intermediate thickening rare to absent, wall thickness 
to $2.75 \mu \mathrm{m}$ wide, cell cavities of median cells brownish red. Cells becoming gradually larger basally, cavities of the basal cells to $40 \mu \mathrm{m}$ long $\times 25 \mu \mathrm{m}$ wide; walls of basal cells with small indistinct trigones and semi-straight walls without any intermediate thickenings, walls and cavities brownish red. Median cells of underleaves vary in shape and size, cells with heavily equally-thickened walls so that the hyaline trigones and intermediate thickenings become indistinct. Median cells of lobule as long as wide or slightly longer than wide, cell cavities to $14 \mu \mathrm{m}$ long $\times 9 \mu \mathrm{m}$ wide; cells near lobule mouth, irregular in shape with flexuose walls, indistinct trigones and occasional small nodulose intermediate thickenings; towards the lobule apex, cells gradually becoming more regular in shape, quadrate to rectangular and the cell walls becoming semi-straight.

Oil bodies of lobe median cells dimorphic. Type One: (1)2(3) per cell, very large, occasionally spherical (2) 3-7 (9) $\mu \mathrm{m}$ in diam. but usually ovoid or ellipsoidal (5) 6-11 (13) $\times(4) 5-10(12) \mu \mathrm{m}$, finely granular, occurs from basal cells through to central region of the lobe, occupying $3 / 4$ to almost the entire cell lumen. Type One oil bodies larger than chloroplasts (if chloroplasts present at all). Type Two: 2-3 (4) oil bodies per cell, typically small, spherical (1) 2-4 (5) $\mu \mathrm{m}$ in diam. to ovoid or ellipsoidal (2) 3-5 (6) $\mu \mathrm{m} \times(1) 2-3$ (4) $\mu \mathrm{m}$, subhyaline, without any significant, visible, internal structure i.e. giving the appearance of being almost homogeneous; these oil bodies often similar in size or slightly smaller than chloroplasts, occasionally slightly larger than chloroplasts. Oil bodies of lobule and underleaf of Type One. Asexual reproduction not recognized.

Plants dioecious, male plants slightly smaller than female plants. Androecia subspherical to spicate, 2-4 (6) pairs of bracts, terminal, usually on very short-stalked branches arising from the main stem, or occasionally from secondary branches (stalk with (1) 2-3 (4) vegetative leaf lobes). Gynoecia terminal on main or leading stem often bearing a subfloral innovation arising 3-4 bract-pair cycles back from the perianth or gynoecia. Innermost bract unequally bilobed; bract-lobe, lobule and innermost bracteole all with entire margins. Bract-lobe ovate to oblong, narrowed toward the rounded or subacute-acute apex, bract-lobule ovate-lanceolate, subacute; innermost bracteole free from bracts, oblong-ovate to oblong-obovate, ca. $1 / 2$ bilobed, lobes convex-sided, subacute at apex, entire margins. Marginal cells of bract and bracteole \pm subequally thickened, but towards the median cells, trigones becoming large and bulging. One archegonium per gynoecium. Perianth freely emergent, $900 \mu \mathrm{m}$ long $\times$ $500 \mu \mathrm{m}$ wide, perianth plicate, 1-2 dorsal keels +2 lateral keels $+1-2$ ventral keels, smooth surface, oblong-ovate, tapering towards the apex into a short beak; perianth beak cylindrical, with a smooth mouth but the inner beak surface densely covered with large single-celled protuberances.

Walls of epidermal layer of capsule wall nodular where the lobes extend irregularly for a short distance over the tangential face toward the centre of the cell and have intermediate thickenings near the middle of the longer walls. Spores globose, 35-45 $\mu \mathrm{m}$ at widest axis, spore wall papillae densely distributed, equatorial face interspersed with 8-10 rosettes, $2.5-3 \mu \mathrm{m}$ wide in the equatorial diameter, bearing a ring of 7-10 conspicuous primary projections, $0.75-1.5 \mu \mathrm{m}$ long $\times 0.5-1.0 \mu \mathrm{m}$ wide at base (often 
with a 1.5-2:1 length to width ratio), tapering gradually to a rounded apex, never papillate or bearing secondary short branches.

Etymology. The species epithet knightbridgei is named in honour and memory of an esteemed New Zealand conservation botanist and ecologist, Phil (Philip) Ian Knightbridge (1969-2011) who passed away in April 2011. This southern species of Aotearoa-New Zealand is a small tribute to Phil by the senior authors who knew him as a colleague and friend.

Distribution and ecology. This species is currently known from only four collections; two from the shore margin of Paterson Inlet, Stewart Island and two from the Auckland Islands. Frullania knightbridgei probably has a more extensive distribution than is currently known and it is quite likely that it resides unrecognized in New Zealand herbaria filed as a form of $F$. rostrata. Nevertheless, it would appear that $F$. knightbridgei is a species of southern distribution and it would be interesting to see if the distribution extends south to the Campbell Islands of the New Zealand botanical region; further field work is required to establish if the species grows on the other two main islands of the New Zealand archipelago, North and South Islands, it should for example be looked for along the Fiordland and Foveaux Strait coastline of the southern South Island. Note the type of $F$. pseudomeyeniana is a high elevation taxon at $1,100 \mathrm{~m}$ whereas the New Zealand taxon is seemingly restricted to or near the shoreline or low elevation.

F. knightbridgei is noteworthy in comparison with the majority of $F$. species in New Zealand for it appears to be a salt tolerant species. This is clearly evident in Stewart Island/Rakiura where F. knightbridgei was growing on twigs of Dracophyllum immediately adjacent the shoreline, at a height of about $50 \mathrm{~cm}$ above the sea. It was evident that for at least some periods of the year, this represented a harsh coastal environment where significant exposure to salt spray from violent wave action would be common. Elsewhere, F. ericoides reportedly develops in rock crevices exposed to sea in the Madeiran archipelago (Sim-Sim and Sergio 1992), and Schuster (1992) reported a variety of $F$. kunzei growing in mature mangrove swamp forest where salt spray and even rare submersion was possible. The high rainfall of the region, providing fresh water, is possibly a critical factor as Engel and Schuster (1973) described for tidal zone liverworts in southern Chile. Interestingly however, Engel and Schuster (1973) noted for Stewart Island a notable "lack of any Hepaticae in the intertidal zone where sea spray is a factor". At least in the New Zealand botanical region, it is clear this is a habitat area that has traditionally been underexplored for liverworts. It would also be interesting to perform glasshouse experiments to investigate test the extent of salt tolerance in these organisms.

Paratypes: Stewart Island: Rakiura/Stewart Island National Park, $500 \mathrm{~m}$. from North Arm Hut, on bark of Dracophyllum longifolium var. longifolium overhanging water on margin of Patterson Inlet, canopy of stunted Dacrydium cupressinum and Metrosideros umbellata, 12 Dec 1999, M. von Konrat 99/12-10 (AK, F); Auckland Island: Open Oreobolus cushion and Chionocloa tussock with scattered groves of Metrosideros, above Ranui Cove, 50³2'12"S, 166¹6'24"E, 11 Dec 1972, R. Common C893B (CHR, F). 


\section{Acknowledgements}

The financial assistance of Caterpillar Inc., National Geographic Committee for Research (Award No. 7379-02), GBIF Seed Money (Award No. 2007/41), and the National Science Foundation (Award Nos. 0949136; 0749762) is gratefully acknowledged. We thank the National Science Foundation for Award No. 1115116 (see http://www.nsf. gov/awardsearch/showAward.do?AwardNumber=1115116) and No. 1115002 (http:// www.nsf.gov/awardsearch/showAward.do?AwardNumber=1115002) that is providing a portal for bryophyte collections and taxonomic data, and to Edward Gilbert for valuable technical support. We thank Anders Hagborg, and Lars Söderström and the Early Land Plants Today (ELPT) project for access to nomenclatural data. Support from the Biodiversity Synthesis Center of the Encyclopedia of Life provided important funding to help foster international initiatives. We are thankful to the Curators of AK, AKU, CANB, BM, CRI, F, G, MEL, MELU, MPN, NICH, NY, P, S, WELT, and WTU for the loan of specimens and to Department of Conservation Staff based at Stewart Island/Rakiura as well as the Southland Conservancy for logistical support. The senior author is deeply grateful to the Department of Conservation, New Zealand, for collecting permits throughout the various Conservancies of New Zealand, particularly Paul Cashmore for facilitating permits. We also thank two anonymous referees and the editor for helpful comments and suggestions as well as the valuable support provided by staff at PhytoKeys. Finally, we thank Joanna McCaffrey for imaging Figure 6.

\section{References}

Bombosch A, Wienecke A, Busch A, Jonas R, Hentschel J, Kreier H-P, Shaw B, Shaw AJ, Heinrichs J (2010) Narrow species concepts in the Frullania dilatata-appalachiana-eboracensis complex: evidence from nuclear and chloroplast DNA markers. Plant Systematics and Evolution 290: 151-158. doi: 10.1007/s00606-010-0357-3

Chown SL, Lee JE, Shaw JD (2008) Conservation of Southern Ocean Islands: invertebrates as exemplars. Journal of Insect Conservation 12: 277-291. doi: 10.1007/978-1-4020-8782-0_7

de Lange PJ, Rolfe JR (2010) New Zealand Indigenous Vascular Plant Checklist List (2010) Wellington, New Zealand Plant Conservation Network, 131pp.

Engel JJ (1978) A taxonomic and phytogeographic study of Brunswick Peninsula (Strait of Magellan) Hepaticae and Anthocerotae. Fieldiana Botany 41: 1-319.

Engel, JJ, Schuster RM (1973) On some tidal zone Hepaticae from South Chile, with comments on marine dispersal. Bulletin of the Torrey Botanical Club 100: 29-35.

Felsenstein J (1985) Phylogenies and the comparative method. American Naturalist 125: 1-15. Given DR, Hnatiuk R (1995) Subantarctic Islands: Australia and New Zealand. Pages 516 - 518 in S. D. Davis, V. H. Heywood and A. C. Hamilton. editors. Centres of Plant Diversity. Volume 2. Asia, Australasia, and the Pacific. WWF/IUCN, IUCN Publications Unit, Cambridge, UK. Glenny D (1998) A revised checklist of New Zealand liverworts and hornworts. Tuhinga 10: 119-149. 
Gradstein SR, Churchill, SP, Salazar-Allen N (2001) Guide to the Bryophytes of Tropical America. New York, The New York Botanical Garden Press, 577 pp.

Gradstein SR, Wilson R, Ilkiu-Borges AL, Heinrichs J (2006) Phylogenetic relationships and neotenic evolution of Metzgeriopsis (Lejeuneaceae) based on chloroplast DNA sequences and morphology. Botanical Journal of the Linnean Society 151: 293-308. doi: 10.1111/j.1095-8339.2006.00531.x

Hall TA (1999) BIOEDIT: a user-friendly biological sequence alignment editor and analysis program for Windows 95/98/NT. Nucleic Acids Symposium Series 41: 95-98.

Hartmann FA, Wilson R, Gradstein SR, Schneider H, Heinrichs J (2006) Testing hypotheses on species delimitations and disjunctions in the liverwort Bryopteris (Jungermanniopsida: Lejeuneaceae). International Journal of Plant Science 167: 1205-1214. doi: 10.1086/508023

Hattori S (1979a) A revision of the Australasian species of the Frullania, Hepaticae, I. Journal of the Hattori Botanical Laboratory 45: 323-363.

Hattori S (1979b) A revision of the Australasian species of the genus Frullania, Hepaticae, II. Journal of the Hattori Botanical Laboratory 46: 119-153.

Hattori S (1983) A revision of the Australasian species of the genus Frullania, Hepaticae, III. Journal of the Hattori Botanical Laboratory 54: 133-182.

Heenan PB, de Lange PJ, Rance BD, Sykes WR, Meurk CD, Korver MA (2009) Additional records of indigenous and naturalised plants with observations on the distribution of Gunnera tinctoria, on Stewart Island, New Zealand. New Zealand Journal of Botany 47: 1-7.

Heinrichs J, Klugmann F, Hentschel J, Schneider H (2009) DNA taxonomy, cryptic speciation and diversification of the Neotropical-African liverwort, Marchesinia brachiata (Lejeuneaceae, Porellales). Molecular Phylogenetics and Evolution 53: 113-121. doi: 10.1016/j.ympev.2009.05.032

Heinrichs J, Hentschel J, Bombosch A, Fiebig A, Reise J, Edelmann M, Kreier H-P, Schäfer-Verwimp A, Caspari S, Schmidt AR, Zhu R-L, von Konrat M, Shaw B, Shaw AJ (2010) One species or at least eight? Delimitation and distribution of Frullania tamarisci (L.) Dumort. s. 1. (Jungermanniopsida, Porellales) inferred from nuclear and chloroplast DNA markers. Molecular Phylogenetics and Evolution 56: 1105-1114, doi: 10.1016/j.ympev.2010.05.004

Hentschel J, von Konrat MJ, Pócs T, Schäfer-Verwimp A, Shaw AJ, Schneider H, Heinrichs J (2009) Molecular insights into the phylogeny and subgeneric classification of Frullania Raddi (Frullaniaceae, Porellales). Molecular Phylogenetics and Evolution 52: 142-156. doi: 10.1016/j.ympev.2008.12.021

Hillis DM, Bull JJ (1993) An empirical test of bootstrapping as a method for assessing the confidence in phylogenetic analysis. Systematic Biology 42: 182-192. doi: 10.1093/sysbio/42.2.182

Holmgren P, Holmgren N (2003) http://www.nybg.org/bsci/ih/ih.html. Updated information available for all herbaria registered in Index herbariorum, based on the Index herbariorum, 8th edition, 1990. New York Botanical Garden Press, New York. [Accessed 05/12/2011]

Mason-Gamer RJ, Kellog EA (1996) Testing for phylogenetic conflict among molecular data sets in the tribe Triticeae (Gramineae). Systematic Biology 45: 524-545. doi: 10.1093/sysbio/45.4.524

Mayden RL (1997) A hierarchy of species concepts: the denouement in the saga of the species problem. Pages 381-424. In Claridge MF, Dawah HA, Wilson MR (Eds) Species. The Units of Biodiversity. Chapman \& Hall, London.

McDade LA (1995) Species concepts and problems in practice: insight from botanical monographs. Systematic Botany 20: 606-622. doi: 10.2307/2419813 
McGlone MS, Wilson HD (1996) Holocene vegetation and climate of Stewart Island, New Zealand. New Zealand Journal of Botany 34: 369-388.

Posada D (2008) jModelTest: Phylogenetic Model Averaging. Molecular Biology and Evolution 25: 1253-1256. doi: 10.1093/molbev/msn083

Ramaiya M, Johnston MG, Shaw B, Heinrichs J, Hentschel J, von Konrat M, Davison PG, Shaw AJ (2010) Morphologically cryptic biological species within the liverwort, Frullania asagrayana. American Journal of Botany 97: 1707-1718. doi: 10.3732/ajb.1000171

Schuster RM (1992) The Hepaticae and Anthocerotae of North America east of the hundredth meridian. Vol. V. Field Museum of Natural History, Chicago.

Sim-Sim M, Sérgio C (1992) Estudo taxonómico e corológico do género Frullania Raddi no Arquipélago da Madeira. Portugaliae Acta Biologica (ser B) 16: 147-172.

Swofford DL (2000) PAUP*, phylogenetic analyses using parsimony (* and other methods), version 4.01b10. Sinauer Associates, Sunderland, Massachusetts.

von Konrat M, Harris PJ, Braggins JE (1999) A new technique to investigate cell layers of the capsule wall using Frullania (Hepaticae) as a case study. The Bryologist 102: 240-248.

von Konrat M, Braggins JE (2001a) A taxonomic assessment of the initial branching appendages in the liverwort genus Frullania Raddi. Nova Hedwigia 72: 283-310.

von Konrat M, Braggins JE (2001b) Notes on five Frullania species from Australia, including typification, synonyms, and new localities. The Journal of the Hattori Botanical Laboratory 91: 229-263.

von Konrat M, Braggins JE (2005) Frullania wairua, a new and seemingly rare liverwort species from Northland, New Zealand. New Zealand Journal of Botany 43: 885-893. doi: 10.1639/0007-2745(2006)109[141:FCJINZ]2.0.CO;2

von Konrat M, Braggins JE, Asakawa Y, Toyota M (2006a) Recognition of Frullania congesta: a case study to present a species concept and a synthesis of significant taxonomic characters for the large liverwort genus Frullania (Frullaniaceae). Journal of the Hattori Botanical Laboratory 100: 553-576.

von Konrat M, Braggins JE, Asakawa Y, Toyota M (2006b) Frullania chevalieri (Jubulaceae) in New Zealand, with a reassessment of Schusterella. The Bryologist 109: 141-156.

von Konrat M, Hentschel J, Heinrichs J, Braggins JE, Pócs T (2010) Forty-one degrees below and sixty years in the dark: Frullania sect. Inconditum, a new section of Australasian Frullania species including F. colliculosa, sp. nov. and F. hodgsoniae, nom. and stat. nov. Nova Hedwigia 91: 471-500. doi: 10.1127/0029-5035/2010/0091-0471

von Konrat M, Hentschel J, Heinrichs J, Braggins JE (2011) Deep Southern Hemisphere Connections: A Revision of Frullania sect. Amphijubula. The Bryologist 114(1): 52-66. doi: 10.1639/0007-2745-114.1.52

Wagstaff SJ, Breitwieser I, Ito M (2011) Evolution and biogeography of Pleurophyllum (Astereae, Asteraceae), a small genus of megaherbs endemic to the subantarctic islands. American Journal of Botany 98: 62-75. doi: 10.3732/ajb.1000238

Wilson H (1987) Vegetation of Stewart Island, New Zealand. Supplement to the New Zealand Journal of Botany, 1-131.

Yuzawa Y (1991) A monograph of subgen. Chonanthelia of gen. Frullania (Hepaticae) of the world. Journal of the Hattori Botanical Laboratory 70: 181-291. 